\title{
Nursing advancement programs: self managed and nursing focused
}

This article was published in the following Dove Press journal:

Nursing: Research and Reviews

23 February 2016

Number of times this article has been viewed

\author{
Mahmoud Salam \\ National Biobanking Section, King \\ Abdullah International Medical \\ Research Center (KAIMRC), King \\ Abdulaziz Medical City (KAMC), \\ Riyadh, Saudi Arabia
}

Correspondence: Mahmoud Salam National Biobanking Section, King Abdullah International Medical Research Center, King Abdulaziz Medical City (KAMC), Ministry of National Guard Health Affairs, PO Box 22490, Mail Code I5 I5, Riyadh II 426, Saudi Arabia Tel +966534284644

Fax+966 II 80I IIII

Email mahmoudsalam@hotmail.com
The nursing body is an integral component of any health care system all over the world, yet it is heading toward crisis. ${ }^{1-3}$ The diversity of health problems demands in return a quality/safe caregiving, which is only privileged to well educated, experienced, and satisfied nurses. ${ }^{4-6}$ The predicted shortfall of $0.5-1$ million registered nurses in the next two decades exerts an inevitable imbalance to the cyclic supply and demand of nurses. ${ }^{7.8}$ In other words, we are heading toward a "perfect storm" where few or lessexperienced nurses care for an ongoing sicker patient population. ${ }^{2}$

Literature has mainly investigated the numerical gap between the projected need for nurses and the estimated bedside nurses in the upcoming years. ${ }^{9}$ The depletion of expert bedside nurses is aggravated by two driving forces: demographics and work-related factors. ${ }^{10,11}$ Demographic factors resemble the individual's personal characteristics such as age, sex, marital status, work experience, and tenure. ${ }^{12-14}$ Work-related factors tend to be more controllable or modifiable, including salaries/incentives, promotions, workload, empowerment, and autonomy. ${ }^{15-18}$ Apparently, when there are not enough enzymes to turn reactants into products, nursing turnover is expected. ${ }^{19}$

Nursing research has found a significant relationship between quality/safe patient outcomes and professional characteristics of nurses. ${ }^{4}$ Expert nurses are capable of grasping clinical situations, utilizing an extensive pattern of skills and making fine distinctions of problems before they even occur. ${ }^{2}$ As per Benner - novice to expert model theorem - most nurses take at least 5 years to reach the expert stage. ${ }^{20}$ Nurses' resignations before reaching this level lead to a dilution of experienced staff, which exerts stressors on junior nurses who see in them their clinical mentors. ${ }^{5}$

In literature, nursing turnover and shortage was generally investigated by researchers descriptively, in terms of rates and associated factors, rather than adopting an interventional methodology. ${ }^{1,2,21}$ Interventional methodologies on this matter create the opportunity of modifying current factors associated with turnovers or introducing new startegies to observe better outcomes. ${ }^{3,5,21}$ For instance, salaries' effect on nurses' satisfaction was debatable in literature. ${ }^{8}$ Some studies found that such variables has a weak impact on work satisfaction, ${ }^{22,23}$ whereas another revealed a strong relationship, thus restricting the nurses' intention to leave their job. ${ }^{16}$ On the same hand, studies proved that by adjusting benefits, work schedule, and other work stressors, it resulted in less turnovers. ${ }^{24} \mathrm{An}$ empowered and autonomous nurse was found to be more satisfied and more likely to be retained. ${ }^{12}$ Promotion opportunities and career development 
emerged as one of the main predictors of nurses' satisfaction that made researchers assertive of the magnitude of such influencing factors. ${ }^{3,4,12}$

Career advancement programs go back to the 1970s, and since that time, it has taken a lot of labels, such as clinical or career advancement programs, nursing advancement programs (NAP), rise program, ${ }^{25}$ clinical nurse advancement system, ${ }^{26,27}$ and others. All these programs targeted health care workers with relatively inflexible career ladders, such as bedside nurses, advanced practice nurses, and faculty. $7,25,27$ Hospital administrators find it impractical to promote nurses within the managerial nursing structure as hospital wards have wide pyramid bases, where a group of nurses is led by one ward manager and/or an assistant. Nurses will eventually be frustrated by the fact of enduring static career status over the years.

Self-efficacy of a bedside nurse entails being competent in achieving the required clinical tasks that earn them perseverance regarding any obstacles they face. ${ }^{4}$ Considering self-efficacy as the minimum standard required, nurses tend to possess additional skills involving accreditation, quality, safety, research, and another nonclinical aspects. Advancement programs are capable of differentiating and recognizing such efforts paid by nurses. In fact, the experience at Cincinnati Children's Hospital Medical Center indicated that nurses advancing in NAP had something earned rather than something simply given for the time spent on the job. ${ }^{7}$

Numerous advantages have been noted on advancement programs, most importantly nurses' retention. ${ }^{7}$ Nurses enrolled in this program reported higher job satisfaction with intentions to enroll again in the upcoming years, thus refraining from leaving bedside. ${ }^{7,28}$ Retention rates in a 4-year advancement program were boosted from $88 \%$ to $97.4 \%$ in one of the hospitals. ${ }^{7}$ Nurses were not only driven by the promotional monetary increase but also by the positive influence on patient outcomes, which is explained by keeping expert nurses in direct care. ${ }^{7,29}$

Establishing a typical advancement program in any health care system requires accomplishing a series of wellconstructed and projected milestones. NAP needs to be nurse centered and career focused, or else, resistance to change is expected. Influential stakeholders and especially those in nursing management are required to be acquainted and involved in such programs as nurses observe them as inspiring team leaders. Research and quality methodologies serve well in assessing the current baseline status, analyzing the progress of program outcomes, and reporting significant changes in nurses' satisfaction, retention, patient outcomes, and other health care indicators. Finally, projected costs and outcome analysis provide a clear vision of the cost versus benefit effectiveness of such programs.

\section{Disclosure}

The author reports no conflicts of interest in this work.

\section{References}

1. Duvall JJ, Andrews DR. Using a structured review of the literature to identify key factors associated with the current nursing shortage. J Prof Nurs. 2010;26(5):309-317.

2. Orsolini-Hain L, Malone RE. Examining the impending gap in clinical nursing expertise. Policy Polit Nurs Pract. 2007;8(3):158-169.

3. Bolton LB, Gassert CA, Cipriano PF. Technology solutions can make nursing care safer and more efficient. $J$ Healthc Inf Manag. 2007;22(4):24-30.

4. Winslow S, DeGuzman P, Kulbok P, Jackson S. Nurses' selfefficacy and academic degree advancement. $J$ Nurses Prof Dev. 2014;30(3):110-116.

5. Clarke T, Kelleher M, Fairbrother G. Starting a care improvement journey: focusing on the essentials of bedside nursing care in an Australian teaching hospital. J Clin Nurs. 2010;19(13-14):1812-1820.

6. Poulin-Tabor D, Quirk RL, Wilson L, et al. Pioneering a new role: the beginning, current practice and future of the Clinical Nurse Leader. J Nurs Manag. 2008;16(5):623-628.

7. Allen SR, Fiorini P, Dickey M. A streamlined clinical advancement program improves RN participation and retention. J Nurs Adm. 2010;40(7/8):316-322.

8. Buerhaus PI. Current and future state of the US nursing workforce. JAMA. 2008;300(20):2422-2424.

9. Buerhaus PI, Staiger DO, Auerbach DI. Is the current shortage of hospital nurses ending? Health Aff. 2003;22(6):191-198.

10. Aiken LH, Clarke SP, Sloane DM, et al. Nurses' reports on hospital care in five countries. Health Aff. 2001;20(3):43-53.

11. Strachota E, Normandin P, O’Brien N, Clary M, Krukow B. Reasons registered nurses leave or change employment status. J Nurs Adm. 2003;33(2):111-117.

12. Al-Momani M. Improving nurse retention in Jordanian public hospitals. Adv Pract Nurs eJournal. 2008;8(4):(1-6).

13. Hall DS. Work-related stress of registered nurses in a hospital setting. J Nurses Prof Dev. 2004;20(1):6-14.

14. Shader K, Broome ME, Broome CD, West ME, Nash M. Factors influencing satisfaction and anticipated turnover for nurses in an academic medical center. J Nurs Adm. 2001;31(4):210-216.

15. Needleman J, Buerhaus P, Mattke S, Stewart M, Zelevinsky K. Nursestaffing levels and the quality of care in hospitals. $N$ Engl $J$ Med. 2002;346(22):1715-1722.

16. Narayanasamy A, Narayanasamy M. Advancing staff development and progression in nursing. Br J Nurs. 2007;16(7):384-389.

17. Barrett L, Yates P. Oncology/haematology nurses: a study of job satisfaction, burnout, and intention to leave the specialty. Aust Health Rev. 2002;25(3):109-121.

18. Evers W, Tomic W, Brouwers A. Aggressive behaviour and burnout among staff of homes for the elderly. Int J Ment Health Nurs. 2002; 11(1):2-9.

19. Sephel A. Digging deeper: nurse excess or shortage?: the effect on a new nurse. J Prof Nurs. 2011;27(6):390-393.

20. Benner P. From Novice to Expert: Excellence and Power in Clinical Nursing Practice. Menlo Park, CA: Addison-Wesley; 1984.

21. Hodges HF, Troyan PJ, Keeley AC. Career persistence in baccalaureateprepared acute care nurses. J Nurs Scholarsh. 2010;42(1):83-91.

22. Zangaro GA, Soeken KL. A meta-analysis of studies of nurses' job satisfaction. Res Nurs Health. 2007;30(4):445-458. 
23. Newman K, Maylor U, Chansarkar B. The nurse satisfaction, service quality and nurse retention chain: implications for management of recruitment and retention. J Manag Med. 2002;16(4):271-291.

24. Gillis A, Jackson W, Beiswanger D. University nurse graduates: perspectives on factors of retention and mobility. Nurs Leadersh (Tor Ont). 2004;17(1):97-110.

25. Knowles BW. The development of a career ladder for acute care case managers. Prof Case Manag. 2008;13(6):331-337.

26. Brenner ZR, Dambaugh L, Hill E, Roberts C, Vollers D. The evolution of clinical nurse advancement. Nurs Manag. 2008;39(10):28-35.
27. Welk DS, Thomas PL. Considering a career change to a nursing faculty position? Key interview questions to ask and why. J Contin Educ Nurs. 2009;40(4):165-170.

28. Nelson JM, Cook PF. Evaluation of a career ladder program in an ambulatory care environment. Nursing Econ. 2007;26(6):353-360.

29. Vollers D, Hill E, Roberts C, Dambaugh L, Brenner ZR. AACN's healthy work environment standards and an empowering nurse advancement system. Crit Care Nurse. 2009;29(6):20-27.

Dove Medical Press encourages responsible, free and frank academic debate. The content of the Nursing: Research and Reviews 'Editorial' section does not necessarily represent the views of Dove Medical Press, its officers, agents, employees, related entities or the Nursing: Research and Reviews editors. While all reasonable steps have been taken to confirm the content of each Editorial, Dove Medical Press accepts no liability in respect of the content of any Editorial, nor is it responsible for the content and accuracy of any Editorial.

Nursing: Research and Reviews

\section{Publish your work in this journal}

Nursing: Research and Reviews is an international, peer-reviewed, open access journal publishing original research, reports, reviews and commentaries on all aspects of nursing and patient care. These include patient education and counselling, ethics, management and organizational issues, diagnostics and prescribing, economics and

\section{Dovepress}

resource management, health outcomes, and improving patient safety in all settings. The manuscript management system is completely online and includes a very quick and fair peer-review system. Visit http://www.dovepress.com/testimonials.php to read real quotes from published authors.

Submit your manuscript here: http://www.dovepress.com/nursing-research-and-reviews-journal 